\title{
Physical Properties of Ice Cream Containing Milk Protein Concentrates
}

\author{
V. B. Alvarez, C. L. Wolters, Y. Vodovotz, and T. Ji \\ Department of Food Science and Technology, \\ The Ohio State University, 2015 Fyffe Road, Columbus 43210
}

\section{ABSTRACT}

Two milk protein concentrates (MPC, 56 and 85\%) were studied as substitutes for 20 and $50 \%$ of the protein content in ice cream mix. The basic mix formula had $12 \%$ fat, $11 \%$ nonfat milk solids, $15 \%$ sweetener, and $0.3 \%$ stabilizer/emulsifier blend. Protein levels remained constant, and total solids were compensated for in MPC mixes by the addition of polydextrose. Physical properties investigated included apparent viscosity, fat globule size, melting rate, shape retention, and freezing behavior using differential scanning calorimetry. Milk protein concentrate formulations had higher mix viscosity, larger amount of fat destabilization, narrower ice melting curves, and greater shape retention compared with the control. Milk protein concentrates did not offer significant modifications of ice cream physical properties on a constant protein basis when substituted for up to $50 \%$ of the protein supplied by nonfat dry milk. Milk protein concentrates may offer ice cream manufacturers an alternative source of milk solids nonfat, especially in mixes reduced in lactose or fat, where higher milk solids nonfat are needed to compensate other losses of total solids.

(Key words: physical property, ice cream, milk protein concentrate)

Abbreviation key: FPM = fat:protein mass, $\mathbf{M P C}=$ milk protein concentrate, $\mathbf{M S N F}=$ milk solids nonfat .

\section{INTRODUCTION}

Ice cream is a high cost-value dairy product. Considerable costs are related to ingredients and energy required for frozen storage, distribution, and retail sale. Consumer acceptance of ice cream depends largely on its textural quality and flavor. However, any temperature fluctuation or abuse between manufacture and consumption can cause detrimental effects on ice cream quality. Increasing levels of milk solids nonfat (MSNF)

Received July 21, 2004.

Accepted November 2, 2004.

Corresponding author: Valenta B. Alvarez; e-mail: alvarez. 23@osu.edu. in ice cream can benefit texture and flavor, but the use of traditional MSNF sources such as NDM (Kilara, 1993) is limited at higher levels due to off-flavors and increased lactose content. Lactose lowers the freezing point of ice cream mixture and increases the occurrence of sandiness in the ice cream. Many alternate sources of MSNF have been studied to replace part or all of the NDM. Alternate MSNF sources include whey protein preparations, caseinates, and UF retentates (Guy, 1980; Parsons et al., 1985; Jensen et al., 1989; Lee and White, 1991; Schmidt, 1994; Haque and Ji, 2003). Isolated protein products alter the original casein:whey ratio found in milk, which can alter physical properties and disrupt the fat destabilization process during ice cream manufacture (Goff et al., 1989). The physical state of fat has a large impact on the physical properties and final structure of ice cream.

Milk protein concentrates (MPC) are relatively new dairy product ingredients that have not yet been studied as an alternate MSNF source in full-fat ice cream formulations. Milk protein concentrates are manufactured by ultrafiltration and diafiltration of milk, followed by a 2 -stage drying process of evaporation and spray drying. The product is high in protein, and low in lactose. Milk protein concentrates maintain the original casein:whey ratio of milk (Novak, 1992). These properties give MPC the potential to serve as an alternate source of MSNF, without some of the drawbacks of traditional sources or alternates studied previously. Before using MPC to replace all or part of the NDM as a source of MSNF in ice cream, MPC functionality needed to be assessed in direct comparison with NDM.

Because there is little information about the use of MPC in ice cream products, a preliminary study was conducted to investigate MPC functionality in ice cream. The results suggested that MPC-substitution might increase mix viscosity, decrease melting rate, and increase shape retention. Larger particle sizes were observed before and after freezing in MPC-substituted mixes compared with the control, indicating possible differences in emulsion destabilization between ice creams with and without MPC. Substitution at higher levels may not be feasible in terms of economic considerations; therefore, the main research efforts focused on lower substitution levels. 
Table 1. Ice cream mix formulas. ${ }^{1}$

\begin{tabular}{lclllll}
\hline $\begin{array}{l}\text { Ingredient } \\
(\%, \text { wt/wt) }\end{array}$ & Control & $\begin{array}{l}20 \% \\
\text { MPC-56 }\end{array}$ & $\begin{array}{l}20 \% \\
\text { MPC-85 }\end{array}$ & $\begin{array}{l}\text { M0\% } \\
\text { MPC-56 }\end{array}$ & $\begin{array}{l}50 \% \\
\text { MPC-85 }\end{array}$ & $\begin{array}{l}\text { Polydextrose } \\
\text { control }\end{array}$ \\
\hline 40\% cream & 30.00 & 30.00 & 30.00 & 30.00 & 30.00 & 30.00 \\
Sucrose & 15.00 & 15.00 & 15.00 & 15.00 & 15.00 & 15.00 \\
Stabilizer/emulsion & 0.30 & 0.30 & 0.30 & 0.30 & 0.30 & 0.30 \\
NDM & 9.78 & 7.49 & 7.49 & 4.06 & 4.06 & 6.57 \\
MPC-56 & 0 & 1.49 & 0 & 3.68 & 0 & 0 \\
MPC-85 & 0 & 0 & 1.02 & 0 & 2.54 & 0 \\
Polydextrose & 0 & 0.82 & 1.29 & 2.09 & 3.21 & 3.21 \\
Water & 44.92 & 44.90 & 44.90 & 44.87 & 44.89 & 44.92 \\
\hline
\end{tabular}

${ }^{1}$ Control mix had no milk protein concentrate (MPC), $20 \%$ and $50 \%$ indicate the amount of protein from MPC substituted in place of NDM, and MPC-56 and MPC-85 indicate the protein content of MPC used. Polydextrose control contained the maximum usage level of polydextrose with no MPC.

It is hypothesized that incorporation of MPC will influence physical properties of the ice cream, thus slowing development of icy texture over time and after heat shock. Furthermore, these influences will be magnified as the MPC protein content or substitution level increases. Therefore, the aim of this study was to assess MPC, on an equal-protein basis as NDM, as an alternate source of MSNF.

\section{MATERIALS AND METHODS}

\section{Ice Cream Mix Formulation and Processing}

Mixes were formulated in $18-\mathrm{kg}$ batches to contain $12 \%$ milk fat, $15 \%$ sugar, $11 \%$ MSNF (with or without polydextrose), and $0.3 \%$ stabilizer/emulsifier, totaling 38.3\% total solids. Mixes incorporating MPC (MPC-56 and MPC-85; Alapro 4560 and 4850, New Zealand Milk Products, Inc., Santa Rosa, CA) contributed 127 and $250 \mathrm{~g}$ of protein from the MPC to substitute 20 and $50 \%$ of the protein of the MSNF, respectively. Polydextrose (Sta-Lite III, A. E. Staley, Decatur, IL) was added to MPC-substituted mixes to compensate for losses in total solids content. A polydextrose control was formulated to contain the maximum amount of polydextrose (583 g) used in replacement of NDM, and no MPC. All 6 experimental mixes (control, MPC-56 (20 and 50\%), MPC-85 (20 and 50\%), and the polydextrose control) were formulated to contain the same amount of fat, protein, sugar, stabilizer/emulsifier, and total solids. Formulas for all mixes are shown in Table 1. Cream (40\%), sugar, and stabilizer/emulsifier (PGX1, Germantown International Ltd., West Chester, PA) were constant throughout all mixes.

A liquefier (Breddo Likwifier, Paul Mueller Co., Springfield, MO) was used to blend wet and dry ingredients. The mixture was pasteurized using a plate heat exchanger (APV Co., Buffalo, NY) at $80^{\circ} \mathrm{C}$ for $25 \mathrm{~s}$, and then homogenized $\left(60^{\circ} \mathrm{C}\right)$ in a 2 -stage process at 14,000 $\mathrm{kPa}(2030 \mathrm{psi})$ and $3500 \mathrm{kPa}(508 \mathrm{psi})$ for the first and second stages, respectively. Mixes were collected in separate sanitized stainless steel milk cans and held overnight at $4^{\circ} \mathrm{C}$ for aging.

All ice cream samples underwent the same handling and freezing conditions. Vanilla extract (VA 30, Virginia Dare, Brooklyn, NY) was added to flavor the mix before freezing at a usage level of $0.4 \%(\mathrm{vol} / \mathrm{vol})$. The mix was frozen in a batch freezer (Coldelite LB-1000, Coldelite Corp., Winston-Salem, NC). The freezer was rinsed with water and sanitized before freezing and between each treatment. The freezer temperature was set and stabilized by running the freezer with $1.90 \mathrm{~L}$ of mix for $10 \mathrm{~min}$, and the mix was then discarded. Three subsequent 3.79-L batches were frozen for each treatment. The order of freezing was randomized. The mix was frozen for $9.5 \mathrm{~min}$ and held an additional 2.5 min to reach the desired overrun of 70 to $80 \%$. The ice cream was added to $360-\mathrm{mL}$ paperboard cups with plastic lids. Draw temperature and overrun for each batch were determined at the time of extraction in triplicate. Filled cups were immediately transferred to a $-40^{\circ} \mathrm{C}$ hardening room and held until further analysis.

\section{Physical Properties of Unfrozen Mix}

Viscosity of the unfrozen mixes was measured using a Brookfield DV-II+ Viscometer (Brookfield Engineering Laboratories, Middleboro, MA) with LV Spindle \#1 before and after aging. All measurements were recorded after $15 \mathrm{~s}$ at $12 \mathrm{rpm}$ and reported as the apparent viscosity.

Emulsion droplet size distribution was determined by laser light scattering (Malvern Mastersizer $\mu+$ Version 2.15, Malvern Instruments Ltd., Worcestershire, UK) on the unfrozen mix before and after aging, and on the frozen ice cream. Samples were dispersed in deionized water at a target obscuration level of $20 \%$. The equivalent surface area mean diameter, $\mathrm{D}[3,2]$, was used to compare fat destabilization that occurred in the sample before and after freezing. 
Freezing behavior of the ice cream mixes was determined using a differential scanning calorimeter (2920 DSC, TA Instruments, Inc., New Castle, DE) equipped with a refrigerated cooling system and operated by Thermal Advantage software (Version 1.1A, TA Instruments, Inc.). Peak integration was performed using Universal Analysis 2000 software (Version 3.0G, TA Instruments, Inc.). Ice cream samples of 10 to $15 \mathrm{mg}$ were weighed into large volume o-ring sealed stainless steel sample pans (Perkin Elmer, Norwalk, CT) and sealed with a Quick Press pan crimper (Perkin Elmer). An empty large volume pan served as the reference. The experimental program of the differential scanning calorimeter consisted of cooling to $-50^{\circ} \mathrm{C}$, holding isothermally for $5 \mathrm{~min}$, and heating at a rate of $5^{\circ} \mathrm{C}$ per minute to $50^{\circ} \mathrm{C}$. Data collected for each mix included the onset melting temperature, temperatures at initial and final deviations from baseline, and peak area, or enthalpy. The onset melting temperature was extrapolated by determining the point of intersection of the tangent drawn at the point of greatest slope on the leading edge of the melting curve peak with the extrapolated base line.

\section{Ice Cream Analysis}

The overrun was calculated on a weight basis using a formula described by Arbuckle (1986). A mix volume (355 mL) was weighed before freezing. The same volume of frozen ice cream was weighed after freezing.

Melting rates were carried out for each sample according to Tharp et al. (1998). Samples were prepared by cutting a $5.0-\mathrm{cm}$ high section $3.8 \mathrm{~cm}$ from the bottom of $355 \mathrm{~mL}$ cylindrical container of ice cream. Samples were tempered for $5 \mathrm{~h}$ in $\mathrm{a}-15^{\circ} \mathrm{C}$ freezer before evaluation. Initial sample weights were recorded. Samples were placed on wire gauze (\#10 mesh) over funnels that were suspended $2.5 \mathrm{~cm}$ above plastic containers placed on digital balances to collect the drip loss. Weights were recorded every $10 \mathrm{~min}$ for $200 \mathrm{~min}$. A plot was created of mass of drip loss divided by the total mass of the ice cream sample vs. time. Melting rates were calculated by determining the equation for the linear portion of the melting data (from 100 to $200 \mathrm{~min}$ ). The slope of the line represented the rate of melting, as percentage mass lost per minute. Fat content was determined in the drip loss collected to assess the extent of the destabilized fat network.

Shape retention was determined by quantitative means within $20 \mathrm{~s}$ of the end of the melting rate analysis. Diameter and height were measured to the nearest millimeter using a vernier caliper (Monostat, Switzerland). Height was measured by inserting the 1-mm diameter stainless steel rod of the caliper into the center of the nonmelted portion of the ice cream remaining on the wire gauze. The small-diameter caliper rod was used to minimize ice cream deformation and error during the measurement.

Sample stability to heat shock was evaluated by sensory assessment of iciness after samples were subjected to abusive conditions of temperature similar to the method used by Tharp et al. (1998). Samples under $-20^{\circ} \mathrm{C}$ storage were heat-shocked by exposure to ambient temperature $\left(21.5 \pm 1.5^{\circ} \mathrm{C}\right)$ for $1 \mathrm{~h}$ and then returned to the freezer. This treatment was repeated each day for 5 consecutive days. One week after the completion of the 5 -d heat shock treatments, samples were sensory analyzed for iciness by a trained panel.

\section{Sensory Analysis}

Sensory analysis was used to evaluate heat shock stability and shelf life quality of ice cream samples (Frazeur and Harrington, 1968; Dolan et al., 1985; Lee and White, 1991). Sensory evaluation of iciness has been found to be a more reliable assessment of ice crystal size influences on texture, as the textural sensory response takes into account other structural elements, such as air and fat that influence the perception of ice crystals (Hartel, 1998). A scale of 0 to 9 was used, with 0 being "not icy" to 9 being "extremely icy". Samples evaluations were made at $1,15,30,45$, and $60 \mathrm{~d}$ of storage. An 8-member panel was trained to identify iciness using previously prepared and selected ice cream samples with different levels of iciness. The training consisted of 16 sessions of 30 min each. Approximately $1.5 \mathrm{~cm}$ of ice cream was first removed from the top of the cup before portioning. Samples of 15 to $20 \mathrm{~g}$ were served in Styrofoam containers with flip-top lids on a bed of dry ice. Sample evaluations were made at $1,15,30,45$, and $60 \mathrm{~d}$ of storage.

\section{Experimental Design}

The experimental design was a randomized complete block, performed in triplicate on separate days (runs), with run as the blocking variable. All analyses were performed in triplicate and were analyzed by 2-way ANOVA with sample and run as the main effects, using SAS statistical software (Release 8.01, SAS Institute, Inc., Cary, NC). Means comparisons were made when the effect was significant $(P<0.05)$ using Fisher's LSD procedure. All results were reported as the combined means of 3 repeated measures from each of the 3 runs made. 
Table 2. Apparent viscosity of ice cream mixes before and after aging. ${ }^{1}$

\begin{tabular}{lcc}
\hline & \multicolumn{2}{c}{ Apparent viscosity $(\mathrm{mPa} \cdot \mathrm{s})$} \\
\cline { 2 - 3 } Sample & Initial & 24-hour aging \\
\hline Control & $112.33 \pm 6.53^{\mathrm{e}}$ & $132.83 \pm 7.03^{\mathrm{b}}$ \\
$20 \%$ MPC-56 & $152.28 \pm 10.63^{\mathrm{cd}}$ & $170.83 \pm 19.44^{\mathrm{a}}$ \\
$20 \%$ MPC-85 & $161.61 \pm 13.18^{\mathrm{bc}}$ & $185.67 \pm 7.66^{\mathrm{a}}$ \\
$50 \%$ MPC-56 & $186.11 \pm 18.38^{\mathrm{a}}$ & $190.94 \pm 9.35^{\mathrm{a}}$ \\
$50 \%$ MPC-85 & $177.72 \pm 16.08^{\mathrm{ab}}$ & $186.94 \pm 13.09^{\mathrm{a}}$ \\
Polydextrose control & $137.78 \pm 19.52^{\mathrm{d}}$ & $145.11 \pm 30.93^{\mathrm{b}}$ \\
\hline \multicolumn{2}{c}{${ }^{\mathrm{a}, \mathrm{b}, \mathrm{c}, \mathrm{d}, \mathrm{e} \text { Means with different letters in the same column are signifi- }}$} \\
cantly different $(P<0.05)$. \\
\multicolumn{2}{l}{${ }^{1}$ Means from triplicate readings from 3 separate batches $(\mathrm{n}=9)}$. \\
${ }^{2} \mathrm{MPC}=$ Milk protein concentrates.
\end{tabular}

\section{RESULTS AND DISCUSSION}

\section{Apparent Viscosity}

All mixes containing MPC were significantly more viscous (152 to $191 \mathrm{mPa} \cdot \mathrm{s})$ than the control (112 to $133 \mathrm{mPa} \cdot \mathrm{s})$ or polydextrose control (138 to $145 \mathrm{mPa} \cdot \mathrm{s})$ (Table 2). The higher mix viscosities in MPC samples can be related the increased voluminosity of the dispersed particles described by the Eilers equation (Walstra et al., 1999). Diafiltration of UF retentates increases the size and weight of casein micelles by the formation of aggregates caused by dissolution of colloidal calcium phosphate (El-Shibiny et al., 1996). This finding suggests that the casein micelles in MPC may contribute more voluminosity than do those found in NDM. This would also explain why mixes with MPC substitution had significantly higher viscosity than the control. Mixes with higher MPC substitution contain more MPC, and thus a greater number of more voluminous casein micelles. DeCastro Morel (1999) reported that MPC of higher protein content generally had longer hydration times compared with MPC of lower protein content because of the presence of a case-hardened shell surrounding the spray-dried particles. There were differences in viscosity among the samples in aged and unaged mixes (Table 2). The range of increases in viscosity due to aging was 4.83 to $24.06 \mathrm{mPa} \cdot \mathrm{s}$. Aging allows for the hydration of proteins and stabilizers, which results in increased viscosity (Berger, 1996; Goff, 2003). The viscosity of the polydextrose control also increased after aging. This suggests that polydextrose may be contributing to increased viscosity, possibly by water binding and increased voluminosity. Polydextrose can readily absorb water and has a higher viscosity than equivalent concentrations of sucrose or sorbitol, possibly due to its highly branched structure (Craig et al., 1996).

\section{Particle Size Analysis of Fat Globules in Emulsion}

Average particle size, D[3,2] showed significant differences in fat globule sizes between the control and polydextrose control samples initially, after aging, and after freezing (Table 3). Aging did not affect the size distribution of fat globules. This result agrees with a previous study that did not show particle size differences in ice cream mixes before and after aging (Gelin et al., 1994). The authors attributed the lack of difference to the fact that no noticeable destabilization of the emulsion had taken place. The fat globule membranes rearrange and become less stable during aging; however, the instability does not change the distribution of fat globules until the occurrence of physical changes during the freezing process. Other researchers have found that little clumping takes place before freezing (Dickinson and Stainsby, 1982). Larger fat globule sizes in the polydextrose control may be explained by the fat:protein mass (FPM) ratio. The FPM ratio has been shown to affect the amount of destabilization of fat globules during ice cream manufacture (Tomas et al., 1994; Gelin et al., 1998). All MPC mixes and the control had similar FPM ratios of approximately 3 (12\% fat: $4 \%$ protein; Table 3). However, the polydextrose control in which polydextrose was substituted for a portion of NDM, had the same fat content as all the other mixes, but lower protein content. The polydextrose mix resulted in a higher FPM ratio of approximately 4 (12\% fat: $3 \%$ protein). Higher FPM ratios have been found to result in larger fat globule sizes (Gelin et al., 1998). The authors concluded that larger fat globule sizes in samples with higher FPM ratios were caused by lack of sufficient protein in the aqueous phase to stabilize the fat globules after homogenization, decreasing the stability of the emulsion. The change in fat globule size after freezing may be related to the stability of the emulsion. In comparing the percentage changes in size distributions among samples, the 20\% MPC-56 mix had the largest percentage increase in fat globule size (129\%; Table 3). The size of the 20\% MPC-56 particles did not differ significantly from the largest particles, found in the polydextrose control. Because the $20 \%$ MPC-56 mix had a lower FPM ratio than the polydextrose control, MPC substitution may also affect emulsion stability when comparing the polydextrose control and 20\% MPC-56 mixes. All MPC mixes showed a greater percentage increase (91 to 129\%) in fat globule sizes compared with control $(70 \%)$. Incorporation of MPC may influence the formation of larger fat globules during freezing. Diafiltration, such as used in the production of MPC, was found to slightly reduce the emulsifying capacity index due to removal of calcium ions (El-Shibiny et al., 1996). Lower emulsifying capacity 
Table 3. Particle size D[3,2] and fat:protein mass (FPM) ratios of ice cream mixes. ${ }^{1}$

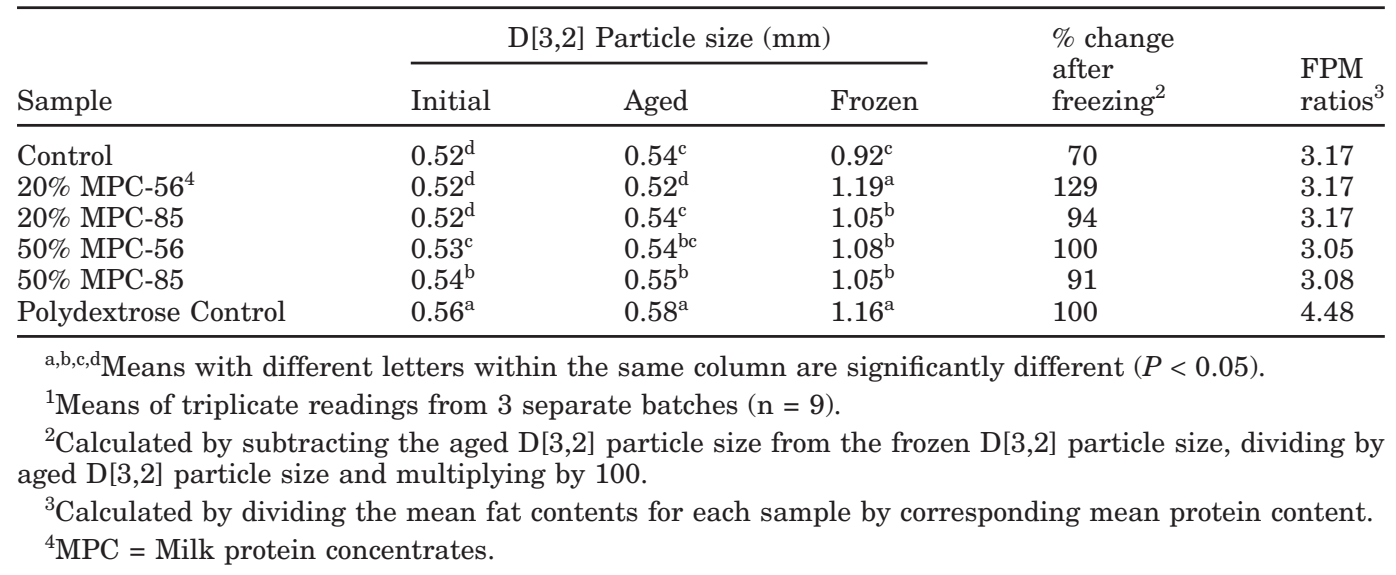

would suggest the formation of less stable emulsions that could undergo greater fat destabilization during freezing, and result in larger fat globule diameters after freezing. Mixes incorporating MPC with higher protein content and at higher substitution levels had significantly smaller fat globule diameters than the polydextrose control or $20 \%$ MPC-56 mixes (Table 3). One possible explanation for a decrease in fat globule size as MPC protein content increases is that increases in drying times and higher heat loads for MPC of higher protein content may result in a greater extent of unfolding and denaturation. Protein unfolding generally causes proteins to become more surface-active and have a greater emulsifying capacity (Damodaran, 1996); this unfolding may overcome any emulsification losses due to calcium losses. A possible explanation for the decrease in fat globule size as substitution level increases is that a greater amount of MPC, with its increased surface activity, may compensate for loss of emulsifying activity seen in lower usage levels.

\section{Differential Scanning Calorimetry}

Differential scanning calorimetry thermograms in all samples tested showed an endothermic peak around $0^{\circ} \mathrm{C}$ that was attributed to ice melting (Figure 1; Vittadini and Vodovotz, 2003) and was therefore used to calculate the amount of "freezable" water. The control mix had more "freezable" water $(51.1 \%)$ associated with the melting curve than the mixes containing MPC (46.6 to $49.5 \%$ ) or polydextrose (46.7\%) (Table 4).

All MPC mixes and the polydextrose control had smaller temperature ranges ( 55.28 to $57.71^{\circ} \mathrm{C}$ ) than the control $\left(60.79^{\circ} \mathrm{C}\right.$; Table 5$)$. The temperature range may be an indicator of the homogeneity of the size distribution of ice crystals, with a narrower range indicating a more homogeneous distribution that melts over a smaller temperature range. Flores and Goff (1999) found smaller spans of ice crystal size distribution in ice cream and solutions with added MSNF, as compared with pure sucrose solution when measured by cryoscanning electron microscopy and image analysis software. The researchers postulated that the microstructures were characterized by a more evenly dispersed arrangement of crystals. Air cells did not play a role in the results from this study because the mix did not undergo the freezing process at this stage. Similarly, ice cream mixes with MPC or polydextrose had a narrower temperature range of ice melting, and therefore, more homogeneous ice crystal size distribution. This explana-

Table 4. Comparisons of moisture content (MC), "freezable" water (FW), and "unfreezable" water (UFW) in ice cream samples.

\begin{tabular}{llll}
\hline Sample & MC $(\%)$ & FW $(\%)$ & $\begin{array}{l}\text { UFW } \\
(\mathrm{MC}-\mathrm{FW})\end{array}$ \\
\hline Control $_{20 \% \text { MPC-56 }}{ }^{1}$ & $61.22 \pm 0.27$ & $51.14 \pm 1.32$ & $10.08 \%$ \\
$20 \%$ MPC-85 & $61.14 \pm 0.38$ & $46.94 \pm 1.05$ & $14.20 \%$ \\
$50 \%$ MPC-56 & $61.01 \pm 0.34$ & $46.58 \pm 1.38$ & $14.43 \%$ \\
$50 \%$ MPC-85 & $60.85 \pm 0.32$ & $48.92 \pm 3.36$ & $11.93 \%$ \\
Polydextrose control & $61.14 \pm 0.48$ & $49.49 \pm 2.01$ & $11.65 \%$ \\
\hline
\end{tabular}

${ }^{1} \mathrm{MPC}=$ Milk protein concentrates. 


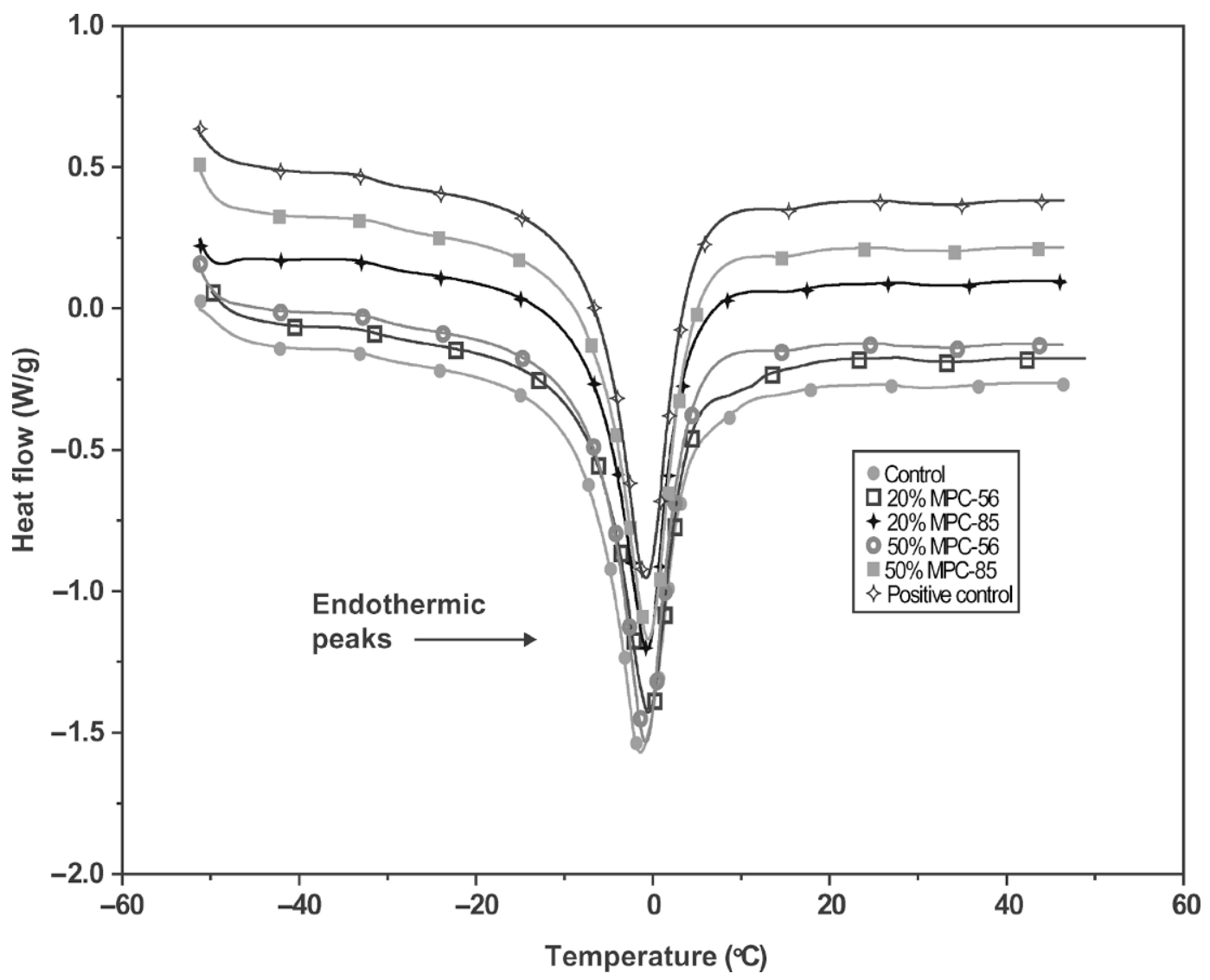

Figure 1. Differential scanning calorimetry melting curves for ice cream samples.

tion is supported by evidence of increased protein denaturation contributing to the decrease of ice crystallization (Peterson and Smith, 1991). Although the mechanism by which polysaccharides exert control over ice crystallization is not agreed upon, polysaccharides have been shown to reduce ice crystal size and growth rates. Polydextrose could be expected to behave in the same manner as other polysaccharides reported in the literature (Chavez-Montes et al., 2003; Regand and Goff, 2003).

\section{Properties of Ice Cream}

Draw temperature of ice cream varied from -5.4 to $-4.7^{\circ} \mathrm{C}$ (Table 6). The lowest draw temperatures were found in the control and polydextrose control mixes. The 50\% MPC mixes had the highest draw temperatures. The temperature of the mix at the completion of the freezing process should relate to the amount of freezing point depression in the mix because all samples were frozen for the same amount of time.

Table 5. Differential scanning calorimetry analyses for ice cream mixes. ${ }^{1}$

\begin{tabular}{llll}
\hline Sample & $\Delta H^{2}(\mathrm{~J} / \mathrm{g})$ & $\begin{array}{l}\text { Onset } \\
\text { temperature }\left({ }^{\circ} \mathrm{C}\right)\end{array}$ & $\begin{array}{l}\text { Temperature } \\
\text { range }\left({ }^{\circ} \mathrm{C}\right)\end{array}$ \\
\hline Control & $170.3 \pm 4.4$ & $-7.12 \pm 0.25$ & $60.79 \pm 0.76^{\mathrm{a}}$ \\
$20 \%$ MPC-56 & $156.3 \pm 3.5$ & $-7.00 \pm 0.13$ & $55.31 \pm 0.03^{\mathrm{c}}$ \\
$20 \%$ MPC-85 & $155.1 \pm 4.6$ & $-6.87 \pm 0.24$ & $55.28 \pm 0.58^{\mathrm{c}}$ \\
$50 \%$ MPC-56 & $162.9 \pm 11.2$ & $-7.06 \pm 0.29$ & $57.71 \pm 0.64^{\mathrm{b}}$ \\
$50 \%$ MPC-85 & $164.8 \pm 6.7$ & $-6.78 \pm 0.11$ & $57.62 \pm 0.85^{\mathrm{b}}$ \\
Polydextrose control & $155.4 \pm 8.4$ & $-6.73 \pm 0.22$ & $55.47 \pm 0.44^{\mathrm{c}}$ \\
\hline
\end{tabular}

${ }^{\mathrm{a}, \mathrm{b}, \mathrm{c}}$ Means with different letters are significantly different $(P>0.05)$.

${ }^{1}$ Means of triplicate readings for each sample.

${ }^{2} \Delta H=$ Overall enthalpy.

${ }^{3} \mathrm{MPC}=$ Milk protein concentrates. 
Table 6. Physical properties of ice cream samples. ${ }^{1}$

\begin{tabular}{lllllll}
\hline & $\begin{array}{l}\text { Draw } \\
\text { temperature } \\
\left({ }^{\circ} \mathrm{C}\right)\end{array}$ & $\begin{array}{l}\text { Overrun } \\
(\%)\end{array}$ & $\begin{array}{l}\text { Melting } \\
\text { rate } \\
(\% / \mathrm{min})\end{array}$ & $\begin{array}{l}\text { Height } \\
(\mathrm{mm})\end{array}$ & $\begin{array}{l}\text { Diameter }^{2} \\
(\mathrm{~mm})\end{array}$ & $\begin{array}{l}\% \text { Fat in } \\
\text { drip loss }^{3}\end{array}$ \\
\hline Control & $-5.42 \pm 0.49^{\mathrm{a}}$ & $65.04^{\mathrm{d}}$ & $0.29^{\mathrm{a}}$ & $15 \pm 1.26$ & $95 \pm 9.68$ & $4.44^{\mathrm{a}}$ \\
$20 \%$ MPC-56 & $-5.06 \pm 0.14^{\mathrm{abc}}$ & $71.92^{\mathrm{b}}$ & $0.27^{\mathrm{bc}}$ & $17 \pm 0.69$ & $91 \pm 2.34$ & $3.64^{\mathrm{b}}$ \\
$20 \%$ MPC-85 & $-4.98 \pm 0.10^{\mathrm{bc}}$ & $74.01^{\mathrm{a}}$ & $0.27^{\mathrm{bc}}$ & $18 \pm 1.17$ & $89 \pm 1.02$ & $3.47^{\mathrm{c}}$ \\
$50 \%$ MPC-56 & $-4.85 \pm 0.12^{\mathrm{c}}$ & $72.54^{\mathrm{ab}}$ & $0.27^{\mathrm{bc}}$ & $17 \pm 0.51$ & $89 \pm 0.67$ & $3.48^{\mathrm{c}}$ \\
$50 \%$ MPC-85 & $-4.68 \pm 0.08^{\mathrm{c}}$ & $68.91^{\mathrm{c}}$ & $0.28^{\mathrm{ab}}$ & $18 \pm 0.77$ & $90 \pm 1.45$ & $3.59^{\mathrm{bc}}$ \\
Polydextrose control & $-5.29 \pm 0.10^{\mathrm{ab}}$ & $68.13^{\mathrm{c}}$ & $0.26^{\mathrm{c}}$ & $19 \pm 2.46$ & $87 \pm 3.69$ & $2.82^{\mathrm{d}}$ \\
\hline &
\end{tabular}

At the freezing point of a mix, latent heat is given off; the more ice frozen at that point and below, the more latent heat is released. Greater depression would cause the temperature of the mix to be lower under identical freezing conditions. The freezing point of an ice cream mix is not directly affected by fat and protein, but is lowered by lactose, sugar, salts, and other substances in true solution (Marshall and Arbuckle, 1996). Therefore, it is expected that the MPC mixes containing less lactose would have higher draw temperatures than the control and polydextrose control mixes. Freezing point depression of the polydextrose control may have resulted from the presence of polydextrose. It has been reported that polydextrose depressed freezing point, but was somewhat less effective than sucrose and sorbitol as a freezing point depressant because of its high molecular weight (Baer and Baldwin, 1984). The authors also stated that high draw temperature or low freezing point of a frozen dessert causes the formation of relatively large ice crystals giving a coarse texture after heat shock. Although the draw temperature of ice cream in the present study (Table 6) shows significant differences $(P<0.05)$, sensory evaluation results indicated no differences in iciness due to heat shock (Table 7). Therefore, such small differences in draw tempera- ture may not be sufficient to affect the mouthfeel of ice cream.

The percentage overrun among mixes differed significantly. Overruns ranged from 64 to $74 \%$, with the control having the least amount of incorporated air, and the 20\% MPC mixes and the 50\% MPC-56 having the highest overruns (Table 6). The presence of MPC may facilitate the initial stabilization of newly formed air bubbles in the freezer better than UF retentates or NDM. Milk protein concentrate is subject to greater total heat load during manufacture than UF retentate due to the incorporation of a drying step (Novak, 1992). Milk protein concentrate is in a more concentrated form than NDM before drying. In this form, the effective heat load is altered, which influences the protein susceptibility to heat. Heat can contribute to protein denaturation and unfolding (Damodaran, 1996), thus, MPC should be slightly more denatured. The greater degree of unfolding may cause the proteins in MPC to absorb onto the air/serum interface faster than proteins from UF retentates or NDM, allowing a greater amount of air to be incorporated under equal freezing conditions. Denatured proteins have been found to have better foaming properties, attributed to increased hydrophobicity, and greater interfacial contact (Phillips et al.,

Table 7. Iciness sensory scores ${ }^{1}$ for 60 -d storage and heat-shocked ice cream. ${ }^{2}$

\begin{tabular}{lllllll}
\hline & \multicolumn{9}{c}{ Days } & \\
\cline { 2 - 6 } Sample & 1 & 15 & 30 & 45 & 60 & Heat-shocked \\
\hline Control & $2.0 \pm 0.9^{\mathrm{a}}$ & $2.3 \pm 1.3^{\mathrm{a}}$ & $1.9 \pm 1.6^{\mathrm{a}}$ & $2.1 \pm 0.8^{\mathrm{a}}$ & $2.0 \pm 1.7^{\mathrm{a}}$ & $4.8 \pm 2.4^{\mathrm{b}}$ \\
$20 \%$ MPC-56 & $1.8 \pm 0.8^{\mathrm{a}}$ & $2.3 \pm 1.1^{\mathrm{a}}$ & $1.8 \pm 1.1^{\mathrm{a}}$ & $1.8 \pm 0.7^{\mathrm{a}}$ & $2.2 \pm 1.0^{\mathrm{a}}$ & $4.3 \pm 2.1^{\mathrm{b}}$ \\
$20 \%$ MPC-85 & $1.9 \pm 1.2^{\mathrm{a}}$ & $2.3 \pm 1.1^{\mathrm{a}}$ & $1.6 \pm 0.9^{\mathrm{a}}$ & $2.1 \pm 1.0^{\mathrm{a}}$ & $2.0 \pm 0.8^{\mathrm{a}}$ & $4.4 \pm 2.1^{\mathrm{b}}$ \\
$50 \%$ MPC-56 & $2.1 \pm 1.1^{\mathrm{a}}$ & $2.4 \pm 1.2^{\mathrm{a}}$ & $2.3 \pm 1.1^{\mathrm{a}}$ & $2.1 \pm 1.0^{\mathrm{a}}$ & $2.0 \pm 1.2^{\mathrm{a}}$ & $4.4 \pm 2.4^{\mathrm{b}}$ \\
$50 \%$ MPC-85 & $1.8 \pm 1.2^{\mathrm{a}}$ & $2.2 \pm 1.5^{\mathrm{a}}$ & $1.8 \pm 1.6^{\mathrm{a}}$ & $1.9 \pm 1.0^{\mathrm{a}}$ & $2.1 \pm 1.2^{\mathrm{a}}$ & $4.2 \pm 2.3^{\mathrm{b}}$ \\
Polydextrose control & $2.2 \pm 0.8^{\mathrm{a}}$ & $1.9 \pm 1.2^{\mathrm{a}}$ & $2.4 \pm 1.3^{\mathrm{a}}$ & $2.1 \pm 0.8^{\mathrm{a}}$ & $2.3 \pm 1.3^{\mathrm{a}}$ & $4.6 \pm 2.3^{\mathrm{b}}$ \\
\hline
\end{tabular}

${ }^{\mathrm{a}, \mathrm{b}}$ Means in rows with different superscripts are significantly different $(P<0.05)$.

${ }^{1}$ Sensory score range $0-9$, score $0=$ not icy, and $9=$ extremely icy.

${ }^{2}$ Means of quadruplicate.

${ }^{3} \mathrm{MPC}=$ Milk protein concentrates. 
1994; Damodaran, 1996). The observations of higher overruns in MPC samples from this study are supported by the results of investigations on overrun using MSNF and UF retentates. The addition of MSNF has been found to increase overrun due to the amphiphilic nature of milk proteins (Flores and Goff, 1999). However, incorporation of UF retentates decreased overrun compared with mixes formulated with condensed skim milk (Jensen et al., 1989).

Samples lost their shape by decreasing in height and increasing in diameter. Therefore, larger height measurements and smaller diameter measurements after melting indicate greater shape retention (Table 6). The control had smaller height dimension $(15 \mathrm{~mm})$ and larger diameter dimension ( $95 \mathrm{~mm}$ ), indicating that the control mix retained less of its original shape than did any of the MPC mixes or the polydextrose control. The polydextrose control retained its diameter more than either the control or 20\% MPC-56 sample. Melting rate and shape retention are dependent on the degree of fat destabilization (Tharp et al., 1998; Walstra and Jonkman, 1998). Therefore, a higher FPM ratio in the polydextrose control may have contributed to the greater retention of shape due to increased fat destabilization. The presence of MPC or polydextrose in the ice cream formulations influenced the shape retention of treated ice cream samples. Polydextrose may contribute to improved shape retention by binding water or reinforcing the existing fat network due to its intricately branched structure (Smiles, 1982; Craig et al., 1996). Milk protein concentrate may have effects on shape retention, as milk proteins have been shown to impart body to ice creams (Goff et al., 1989). Another proposed mechanism for protein effects on body and texture is the formation of networks of phase-separated milk proteins and polysaccharides (Syrbe et al., 1998). The presence of polydextrose as an additional polysaccharide in the experimental mixes in this study may have increased the chances of this protein-polysaccharide interaction occurring.

The fat content in the drip loss differed significantly among the ice cream samples (Table 6). The control samples contained significantly higher amounts of fat in the drip loss (4.4\%) than the MPC samples and the polydextrose control. The polydextrose control had significantly less fat in the drip loss (2.8\%) than the MPC samples and control. Higher degrees of fat destabilization result in less fat content in the drip loss of melted ice cream samples (Tharp et al., 1998; Bolliger et al., 2000). Therefore, the same influences of MPC and polydextrose on fat globule sizes may explain the observed differences in fat content in the drip loss.

Although the sample melting rates (Table 6) show significant differences, the results are so close together that they cannot be considered truly different. Therefore, MPC or polydextrose in ice cream had only minimum effect on the melting rate under the conditions of this study.

\section{Sensory Analysis}

Mean iciness scores among samples and across all points of the 60-d shelf life study ranged from 1.6 to 2.4 out of 9.0 , which is extremely icy (Table 7). Iciness scores did not differ significantly at each time point and no discernible trend in iciness was observed as time increased. Under constant storage conditions at a temperature below freezing, development of an icy texture takes place very slowly. Samples held at a constant low temperature $\left(-20\right.$ to $\left.-30^{\circ} \mathrm{C}\right)$ have been shown to have slight to no change on the overall ice crystal size of ice cream samples compared with samples held at higher temperatures (Earl and Tracy, 1960; Frazeur and Harrington, 1968; Donhowe and Hartel, 1996; Flores and Goff, 1999). Samples for this shelf life study were kept at $-20^{\circ} \mathrm{C}$, which falls in the range of storage temperature thought to have little change in ice crystal size. Therefore, stable storage conditions at a low temperature may have prevented the observance of noticeable texture differences during the course of the shelf life study.

Length of storage may be another factor in the lack of differences on iciness scores. Sixty days may be not enough time to observe the development of icy texture. It was reported that ice creams held at $-18^{\circ} \mathrm{C}$ for 6 mo were degraded slightly in texture (Smith and Dowd, 1961).

The sensory results of iciness scores over a 60 -d shelf life suggest that any differences between MPC and control mixes in textural quality, if present, are very small and are not observable via sensory means at $60 \mathrm{~d}$. This is in agreement with results from previous studies conducted with UF retentates in substitution of a percentage of NDM. It was reported that there were no significant differences in overall flavor, body, and texture scores, including iciness, among ice cream samples substituted with 25 to $75 \%$ UF retentates and a control mix with no UF retentates (Lee and White, 1991). Another study showed that ice creams made with UF retentates were similar to ice creams made solely with NDM as evaluated by sensory means (Geilman and Schmidt, 1992).

Iciness sensory scores of the ice cream samples after heat shock showed significant differences $(P<0.05)$ compared with the nonheat-shocked samples (Table 7). However, there were not significant differences among the heat-shocked samples. The maintenance of constant protein levels across the control and MPC samples is 
the likely explanation for no difference in heat shock protection. Studies of heat shock resistance using alternate forms of MSNF found only slight differences between control and experimental mixes. Ice creams made with UF retentates had better heat shock protection, as analyzed through sensory means, than control or mixes with whey protein concentrates (Lee and White, 1991). The researchers concluded that the higher casein levels in UF retentate mixes contributed to heat shock protection by increasing water-binding capacity compared with samples made with whey protein concentrates. However, the authors studied higher ranges of substitution with UF retentate ( 25 to $75 \%$ ) than used in this study. Furthermore, the control and whey protein concentrate mixes had lower protein contents $(2.9 \%$ for the control, 3.2 to $3.6 \%$ for the whey protein concentrate mixes) compared with the UF retentate samples (4.0 to $4.5 \%$ ). Therefore, the observed improvements in heat shock stability observed by Lee and White may have been caused by the increase in protein content of the UF retentate mixes. The MPC mixes in this study did not differ from the control in protein content, which may explain why differences in heat shock protection were not observed.

\section{CONCLUSIONS}

Examination of selected physical properties showed significant differences among samples formulated with MPC and polydextrose compared with the control. The properties of the unfrozen mix and the frozen product differed among MPC samples and between MPC samples and the control. Although no textural improvements in iciness development were apparent from use of MPC in place of NDM, the small differences in physical properties suggest that MPC could be incorporated to produce a suitable ice cream. This may be important when considering alternate sources of MSNF to replace NDM for production of reduced-lactose ice cream. Furthermore, the effects of MPC incorporation in ice cream may be more apparent and more beneficial in reduced or fat-free applications.

\section{REFERENCES}

Arbuckle, W. S. 1986. Ice cream. 4th ed. AVI Publishing Co., Westport, CT.

Baer, R. J., and K. A. Baldwin. 1984. Freezing points of bulking agents used in manufacture of low-calorie frozen desserts. J. Dairy Sci. 67:2860-2862.

Berger, K. G. 1996. Ice cream. Pages 413-490 in Food Emulsions. 3rd ed. K. Larson and S. E. Friberg, ed. Marcel Dekker, New York, NY.

Bolliger, S., H. D. Goff, and B. W. Tharp. 2000. Correlation between colloidal properties of ice cream mix and ice cream. Int. Dairy J. 10:303-309.

Chavez-Montes, B. E., L. Choplin, and E. Schaer. 2003. Rheo-reactor for studying the processing and formulation effects on structural and rheological properties of ice cream mix, aerated mix and ice cream. Polym. Int. 52:572-575.

Craig, S. A. S., J. M. Anderson, J. F. Holden, and P. R. Murray. 1996. Bulking agents. Pages 217-230 in Carbohydrates as organic raw materials III. H. Van Bekkum, H. Roper, and A. G. J. Voragen, ed. New York, NY.

Damodaran, S. 1996. Amino acids, peptides, and proteins. Pages 251276 in Food Chemistry. 3rd ed. O. Fennema, ed. Marcel Dekker, New York, NY.

DeCastro Morel, M. 1999. Influence of spray dryer air outlet temperature and nozzle orifice diameter on characteristics of high-protein milk protein concentrate (MPC). Ph. D. Diss. The Ohio State University, Columbus.

Dickinson, E., and G. Stainsby. 1982. Colloids in Foods. Applied Science Publishers, London, UK.

Dolan, K. D., R. P. Singh, and J. H. Wells. 1985. Evaluation of timetemperature related quality changes in ice cream during storage. J. Food Proc. Pres. 9:253-271.

Donhowe, D. P., and R. W. Hartel. 1996. Recrystallization of ice in ice cream during controlled accelerated storage. Int. Dairy J. 6:1191-1208.

Earl, F. S., and P. H. Tracy. 1960. The importance of temperature in the storage of ice cream. Ice Cream Trade J. 56(11):36-37, 40, $42,78-80$.

El-Shibiny, S., N. M. Shahein, and M. El-Shiekh. 1996. Preparation and functional properties of UF whole milk protein isolates. IDF Bull. 311:28-30.

Flores, A. A., and H. D. Goff. 1999. Ice crystal size distributions in dynamically frozen model solutions and ice cream as affected by stabilizers. J. Dairy Sci. 82:1399-1407.

Frazeur, D. R., and R. B. Harrington. 1968. Low temperature and conventionally frozen ice cream. 1 . The effect of storage conditions and heat shocks on body and texture. Food Tech. 22:910-912.

Geilman, W. G., and D. E. Schmidt. 1992. Physical characteristics of frozen desserts made from ultrafiltered milk and various carbohydrates. J. Dairy Sci. 75:2670-2675.

Gelin, J. L., P. Barey, and L. Poyen. 1998. Assessment of fat destabilization in ice cream using laser light scattering. Page 193 in Ice Cream. W. Buchheim, ed. International Dairy Federation, Brussels, Belgium.

Gelin, J. L., L. Poyen, J. L. Courthaudon, M. Le Meste, and D. Lorient. 1994. Structural changes in oil-in-water emulsions during the manufacture of ice cream. Food Hydrocoll. 8:299-308.

Goff, H. D. 2003. Ice Cream. Pages 1063-1082 in Advanced Dairy Chemistry Vol. 1. Proteins. 3rd ed. P. F. Fox, and P. L. H. McSweeney, ed. Kluwer Academic/Plenum Publishers, New York, NY.

Goff, H. D., J. E. Kinsella, and W. K. Jordan. 1989. Influence of various milk protein isolates on ice cream emulsion stability. J. Dairy Sci. 72:385-397.

Guy, E. J. 1980. Partial replacement of nonfat milk solids and cane sugar in ice cream with lactose-hydrolyzed sweet whey solids. J. Food Sci. 45:129-133.

Haque, Z. U., and T. Ji. 2003. Cheddar whey processing and source. II. Effect on non-fat ice cream and yoghurt. Int. J. Food Sci. Technol. 38:463-473.

Hartel, R. W. 1998. Phase transitions in ice cream. Pages 327-368 in Phase/state transitions in foods: Chemical, structural, and rheological changes. M. A. Rao and R. W. Hartel, ed. Marcel Dekker, New York, NY.

Jensen, L. A., P. S. Tong, and L. Harris. 1989. Characteristics of frozen desserts containing retentate from ultrafiltration of skim milk. Part I. Mix composition and freezing. J. Dairy Sci. 72(Suppl.):129. (Abstr.)

Kilara, A. 1993. Formulating frozen desserts. Dairy Foods 9:69-70.

Lee, F. Y., and C. H. White. 1991. Effect of ultrafiltration retentates and whey protein concentrates on ice cream quality during storage. J. Dairy Sci. 74:1170-1180.

Marshall, R. T., and W. S. Arbuckle. 1996. Ice Cream. 5th ed. Chapman \& Hall, New York, NY.

Novak, A. 1992. Milk protein concentrate. Pages 51-56 in New Applications of Membrane Processes. International Dairy Federation, 
Special Issue No. 9201, International Dairy Federation, Brussels, Belgium.

Parsons, J. G., S. T. Dybing, D. S. Coder, K. R. Spurgeon, and S. W. Seas. 1985. Acceptability of ice cream made with processed wheys and sodium caseinate. J. Dairy Sci. 68:2880-2885.

Peterson, S. D., and D. E. Smith. 1991. Extent of protein denaturation in heated solutions of whey protein isolate (WPI), with and without added sucrose, and its correlation to freezing characteristics of the solutions. J. Dairy Sci. 74(Suppl. 1):128. (Abstr.)

Phillips, L. G., D. M. Whitehead, and J. Kinsella. 1994. Structurefunction properties of food proteins. Academic Press, Inc., San Diego, CA.

Regand, A., and H. D. Goff. 2003. Structure and ice recrystallization in frozen stabilized ice cream model systems. Food Hydrocoll. 17:95-102.

Schmidt, K. 1994. Effect of milk proteins and stabilizer on ice milk quality. J. Food Qual. 17:9-19.

Smiles, R. E. 1982. The functional applications of polydextrose. Pages 305-322 in Chemistry of Food and Beverages: Recent Developments. G. Charalambous and G. Inglett, ed. Academic Press, New York, NY.
Smith, A. C., and L. R. Dowd. 1961. Effect of ice cream packaging material on quality of ice cream. Ice Cream Trade J. 57:10.

Syrbe, A., W. J. Bauer, and H. Klostermeyer. 1998. Polymer science concepts in dairy systems-An overview of milk protein and food hydrocolloid interaction. Int. Dairy J. 8:179-193.

Tharp, B. W., B. Forrest, C. Swan, L. Dunning, and M. Hilmoe. 1998. Basic factors affecting ice cream meltdown. Pages 54-64 in Ice Cream. W. Buchheim, ed. International Dairy Federation Special Issue 9803. International Dairy Federation, Brussels, Belgium.

Tomas, A., D. Paquet, J. L. Courthaudon, and D. Lorient. 1994. Effect of fat and protein contents on droplet size and surface protein coverage in dairy emulsions. J. Dairy Sci. 77:413-417.

Vittadini, E., and Y. Vodovotz. 2003. Changes in the physicochemical properties of wheat- and soy-containing breads during storage as studied by thermal analyses. J. Food Sci. 68:2022-2027.

Walstra, P., T. J. Geurts, A. Noomen, A. Jellema, and M. A. J. S. van Boekel. 1999. Dairy technology: Principles of milk properties and processes. Marcel Dekker, New York, NY.

Walstra, P., and M. Jonkman. 1998. The role of milkfat and protein in ice cream. Pages 17-24 in Ice Cream. W. Buchheim, ed. International Dairy Federation Special Issue 9803. International Dairy Federation, Brussels, Belgium. 